\title{
Pleomorphic Lipoma
}

See Chap. 236.

(C) The Editor(s) (if applicable) and The Author(s), under exclusive license to 